Chirurgia (2020) 115: 227-235

No. 2, March - April

Copyright@ Celsius

http://dx.doi.org/10.21614/chirurgia.115.2.227

\title{
The Influence of the Type of Surgery on the Immediate Postoperative Results in Patients with Colorectal Cancer Operated in Emergency
}

\author{
Georgiana Bianca Constantin ${ }^{1}$, Dorel Firescu, ${ }^{2,3}$, Dragoș Voicu' ${ }^{2}$ Bogdan Ștefănescu ${ }^{2,3}$, Raul Mihailov', \\ Cristina Șerban ${ }^{2,3}$, Eugenia Panaitescu', Rodica Bîrlă ${ }^{1,4}$, Silviu Constantinoiuu, \\ ${ }^{1}$ Carol Davila University of Medicine and Pharmacy, Bucharest, Romania \\ ${ }^{2}$ Dunarea de Jos University, Faculty of Medicine and Pharmacy, Galati, Romania \\ ${ }^{3}$ Clinical Emergency County Hospital Sf. Ap. Andrei, Galati, Romania \\ ${ }^{4}$ General and Esophageal Surgery Department, Center of Excellence in Esophageal Surgery, Saint Mary Clinical Hospital, \\ Bucharest, Romania
}

Corresponding author:

Rodica Birla, MD

General and Esophageal Surgery

Department, Center of Excellence

in Esophageal Surgery

Sf. Maria Clinical Hospital

Bucharest, Romania

E-mail: birlarodica@ahoo.com
Received: 20.02 .2020

Accepted: 26.03 .2020

\section{Rezumat}

Influența tipului de intervenție chirurgicala asupra rezultatelor postoperatorii imediate la pacienții cu cancer colorectal operați în regim de urgență

Introducere: Chirurgia de urgență a cancerului colo-rectal este asociată cu rate mari de morbiditate şi mortalitate, cauzate de factori care țin de caracteristicile pacienților, dar şi de atitudinea terapeutică. Scopul studiului este de a identifica intervențiile chirurgicale asociate cu complicațiile postpoperatorii, cu cauzele principale de morbiditate, $\mathrm{cu}$ reintervențiile chirurgicale şi $\mathrm{cu}$ decesele postoperatorii.

Pacienti şi metode: Am inclus în acest studiu retrospectiv 431 pacienți internați şi operați în regim de urgență pentru cancer colorectal complicat, în Clinica Chirurgie II a Spitalului Clinic Județean de Urgență "Sf. Ap. Andrei” din Galați, în perioada 20082017. Datele pacientilor au fost colectate din foile de observatie, protocoalele operatorii şi buletinele histo-patologice, imagistice şi de laborator, la momentul intervenției de urgență, precum şi din cele din internările ulterioare pentru cei care au beneficiat de interventiii seriate.

Rezultate: Morbiditatea postoperatorie a fost 10,44\%. Rezecția cu anastomoză s-a asociat cu prezența complicațiilor postoperatorii $(p<0.01)$ : cu colita pseudomembranoasă $(p<0.01)$, cu ocluzia intestinală postoperatorie $(\mathrm{p}<0.01)$. Practicarea limfodisecției s-a asociat $\mathrm{cu}$ apariția complicaților postoperatorii $(\mathrm{p}<0.01)$ : a colitei 
pseudomembranoase $(p<0.01)$ şi a ocluziei intestinale $(p<0.01)$. Reinterventiile $\mathrm{s}^{-} \mathrm{au}$ asociat cu rezecțiile cu anastomoză $(\mathrm{p}<0.01)$, cu practicarea limfodisecției $(\mathrm{p}<0.01)$ sau cu pacienții cu abdomen semideschis/deschis $(\mathrm{p}<0.04)$. Mortalitatea postoperatorie a fost de $9,28 \%$. S-a asociat cu practicarea limfodisecției $(\mathrm{p}<0.01)$, a ileostomei $(\mathrm{p}<0.01)$, cu abdomenul semideschis/deschis $(\mathrm{p}<0.04)$. Cel mai mic număr al zilelor de spitalizare l-au avut pacienții cu colostomie $(\mathrm{p}<0.01)$.

Concluzii: Rezecțiile cu anastomoză per primam şi practicarea limfodisecției s-au asociat cu o morbiditate mai mare. Tipul de intervenție chirurgicală principală nu a influențat mortalitatea postoperatorie, aceasta fiind asociată cu intervențiile chirurgicale concomitente: limfodisecția, ileostoma de protecție şi modalitatea de închidere a abdomenului. Reintervențiile au fost asociate cu rezecțiile cu anastomoză per primam, cu practicarea limfodisecției şi cu abdomenul semidechis/deschis. Durata spitalizării a fost semnificativ mai mică la pacienții cu colostomie.

Cuvinte cheie: cancer colorectal complicat, chirurgie urgență, rezultate, morbiditate, mortalitate

\begin{abstract}
Introduction: The emergency surgery for colorectal cancer is associated with high rates of morbidity and mortality due to factors related to the characteristics of the patients but also the therapeutic attitude. This study aims to identify the surgical interventions associated with the postoperative complications, with the main causes of morbidity, with the reinterventions and with the postoperative deaths.

Patients and methods: We included in this retrospective study 431 patients hospitalized and operated in an emergency for complicated colorectal malignant tumors in the Surgery II Clinic of the Clinical Emergency County Hospital "Sf. Ap. Andrei "from Galati, in the period 2008-2017. The patients' data were collected from observation sheets, operative protocols, pathological, imaging and laboratory bulletins, at the time of the emergency intervention, as well as from those of subsequent admissions in patients who benefited from serial interventions.

Results: The postoperative morbidity was $10.44 \%$. The resections with anastomosis were associated with the presence of postoperative complications $(\mathrm{p}<0.01)$ : pseudomembranous colitis, $(p<0.01)$ and postoperative intestinal occlusion $(p<0.01)$. The practice of lymph node dissection was associated with postoperative complications $(p<0.01)$ : pseudomembranous colitis $(p<0.01)$ and intestinal occlusion $(\mathrm{p}<0.01)$. The reinterventions were associated with resections with anastomosis $(p<0.01)$, lymph node dissection $(p<0.01)$ or patients with open /semi-open abdomen $(p<0.04)$. The postoperative mortality was $9.28 \%$. It was associated with the practice of lymph node dissection $(\mathrm{p}<0.01)$, of the ileostomy $(\mathrm{p}<0.01)$, with the open /semi-open abdomen $(\mathrm{p}<0.04)$. Patients with colostomy had the lowest number of hospitalization days $(\mathrm{p}<0.01)$.

Conclusions: The resections with anastomosis per primam and the lymph node dissection were associated with morbidity. The type of main surgery did not influence the postoperative mortality, this being associated with the concomitant surgery: the lymph node dissection, the ileostomy, and the abdomen closure type. The reinterventions were associated with resections with anastomosis per primam, with lymph node dissection and with the open /semi-open abdomen. The duration of hospitalization was significantly shorter in patients with a colostomy.
\end{abstract}

Key words: complicated colorectal cancer, emergency surgery, results, morbidity, mortality

\section{Introduction}

Emergency surgery for colorectal cancer is associated with high rates of morbidity and mortality (1). This fact is caused by various factors related to the characteristics of the 
patients who are subjected to such operations (age, comorbidities, biological status), but also by the therapeutic attitude and the tumor aggressivity. Besides, the colorectal cancer emergency surgery is also associated with a high percentage of stomas (temporary or definitive) (2). These poor postoperative results were attributed to the technical difficulties, the instability of the patients, the incomplete lymph node dissection leading to understaging (3). For patients who present in an emergency with perforated tumors, the cause of the high rate of postoperative mortality is the multiple organ dysfunction, given by fecaloid peritonitis (4).

No consensus has yet been reached on the factors on which the results of the various types of emergency surgery for complicated colorectal cancer depend, in particular, the choice of the type of surgery in obstructions of the left colon remains controversial $(2,5)$. In the literature, numerous studies analyze the safety of different types of emergency surgery for complicated colorectal cancer in terms of postoperative morbidity and mortality and the results differ greatly. Some authors believe that one-time operations are reasonable (5-8), others have reported significantly lower morbidity and mortality in the case of serial interventions (9-11).

Although the Hartmann operation is associated with relatively low mortality (2.6$9 \%$ ), serial interventions still have an inherent problem, especially in the elderly, with many hospitalizations, in which the stoma reversal will often no longer be realized. For those with stoma reversal, the morbidity ranges from 5 to $57 \%$ and the mortality from 0 to $34 \%$ (12). According to WSES recommendations, Hartmann's procedure does not provide a benefit in terms of postoperative morbidity and mortality compared with resections with anastomosis in left colon obstructive cancer (recommendation grade $2 \mathrm{C}+$ ); Hartmann interventions should be considered in patients at increased surgical risk (recommendation grade 2C) (5).

\section{Patients and Methods}

We included in this retrospective study 431 patients hospitalized and operated in an emergency for complicated colorectal malignant tumors in the Surgery II Clinic of the Clinical Emergency County Hospital "Sf. Ap. Andrei " from Galati, in the period 2008-2017.

The patients' data were collected from observation sheets, operative protocols, pathological, imaging and laboratory bulletins, at the time of the emergency intervention, as well as from those of subsequent admissions in patients who benefited from serial interventions. We performed a descriptive analysis of the tumors' location as well as the practiced types of surgery. We analyzed the immediate postoperative results evaluated by the postoperative morbidity and mortality, the necessity of the surgical reinterventions, the duration of the hospitalization, as well as the medium-term results -the stoma reversal after Hartmann operations or other serial interventions. We made correlations with the type of main intervention, the associated surgical interventions: lymph node dissection, splenectomy, ileostomy, liver biopsy, other associated interventions and the way of abdomen closure.

\section{Study Design}

The patients included in this study were grouped according to the presence or absence of morbidity factors, reinterventions, and post-operative deaths. There were made correlations of the presence of postoperative complications, parietal suppurations, pseudomembranous colitis, anastomotic fistulas, postoperative occlusion, reinterventions and postoperative deaths with the type of main intervention, lymph node dissection, ileostomy, liver biopsy, splenectomy, other associated interventions, and abdomen closure.

\section{Statistical analysis}

We made statistical correlations between each of the main or associated types of surgery and 
the presence of postoperative complications, the main causes of morbidity, the reinterventions and the postoperative deaths. For these, we used the p-value obtained with the PearsonChi Square, Fisher Exact and Likelihood Ratio tests or the Kruskal-Wallis test (to correlate the length of hospitalization). The statistical conclusions were formulated using a statistically significant difference threshold value $p<0.05$ for all assessments performed.

\section{Results}

In 60 cases $(13.92 \%)$ the tumors were located at the level of the cecum, ascendant and the hepatic angle of the colon, in 30 cases $(6.98 \%)$ at the level of the transverse colon, 57 tumors $(13.22 \%)$ were at the descending colon and splenic angle, $133(30.85 \%)$ at the sigmoid and recto-sigmoid junction and $151(35.03 \%)$ were rectal tumors (Fig. 1).

There were 179 (41.5\%) external derivations (158 colostomies and 21 Pezzer cecostomies), 134 (31.1\%) Hartmann operations, 89 (20.9\%) resections with anastomosis (47 right hemicolectomies, 13 left hemicolectomies, 26 transverse/sigmoid / descending segmental colectomies, 1 subtotal colectomy, 1 ileotransverse anastomotic resection for a relapsed tumor and 1 rectal tumor resection with mechanical anastomosis) and 29 internal derivations (16 ileo-transverse anastomoses, 9 transversedescending, 2 ileo-sigmoid, 1 ileo-descendant, and 1 transverse-sigmoid) (Fig. 2).

In 6 cases $(1.39 \%)$ it was considered necessary to practice a protective ileostomy. Lymph node dissection was performed in 76 cases $(17.63 \%)$, especially in patients with tumors located on the right colon, when the surgery of choice was right hemicolectomy/enlarged right hemicolectomy. Tactical splenectomy was associated in 7 cases $(1.62 \%)$, when splenic angle tumors were adherent to the spleen, making the dissection impossible.

Liver biopsy (from the macroscopic aspect of secondary disseminations) was performed in 17 patients (3.94\%). The intraoperative suspicion of metastasis (or preoperative ultrasound) was confirmed pathologically in all

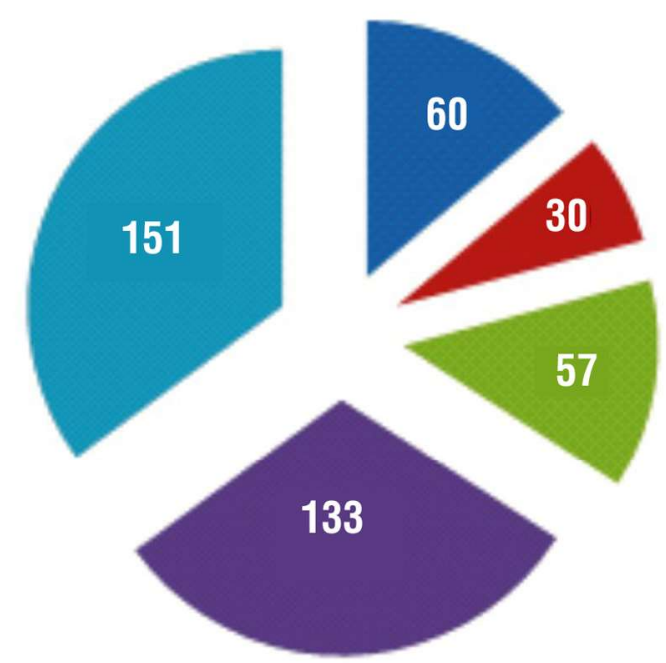

Cecum, ascendant, hepatic angle

Transverse

Descendant, splenic angle

Sigmoid, recto-sigmoid junction

- Rectum

Figure 1. Distribution of cases according to the location of tumors at the colo-rectal level

cases. In 12 patients, other associated interventions were performed (such as the treatment of incarcerated hernias).

Most of the times, in 417 cases (96.75\%), a classical abdomen closure was performed and only in 11 cases $(2.55 \%)$ it was practiced a semi-open abdomen on Georgescu rings or even open abdomen in 3 cases $(0.69 \%)$ with tumor perforation, when it was considered that the septic source was not completely resolved in an emergency, with scheduled

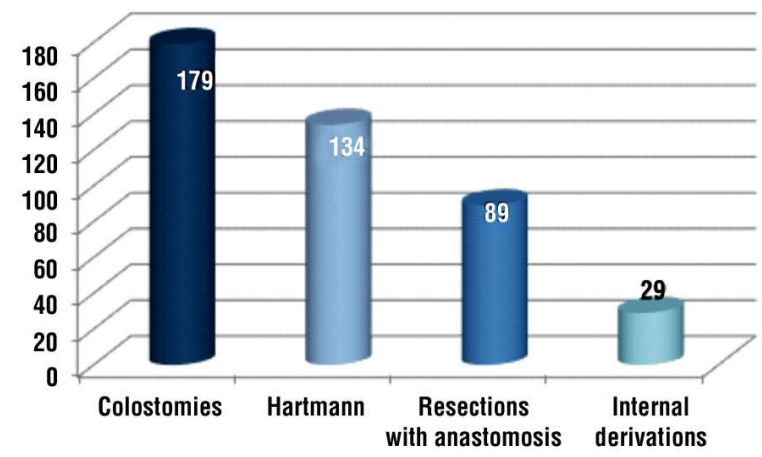

Figure 2. Distribution of the types of surgery performed in an emergency 
reinterventions for peritoneal lavage.

The percentage of postoperative morbidity was $10,44 \%$ (Fig. 3).

$45(10.44 \%)$ of the patients included in the study had postoperative complications, such as 23 parietal suppurations, 5 pseudomembranous colitis (reported as nosocomial infection with Clostridium difficile), 12 anastomotic fistulas and 5 postoperative occlusions (with reinterventions) (Fig. \).

The resections with anastomosis were associated with the presence of postoperative complications $(p<0.01)$, with the postoperative pseudomembranous colitis, $(p<0.01)$, with postoperative intestinal occlusion - all 5 cases with this complication occurred in patients with resections with anastomosis $(\mathrm{p}<0.01)$ (Table 1).

The lymph node dissection was associated with postoperative complications $(p<0.01)$ : pseudomembranous colitis $(\mathrm{p}<0.01)$ and postoperative intestinal occlusion $(\mathrm{p}<0.01)$ (Table 1). The postoperative complications were not associated with an ileostomy, splenectomy, liver biopsy or other associated interventions (Table 1).

The patients with open and semi-open abdomen were associated with the presence of postoperative complications $(\mathrm{p}<0.04)$ - postoperative fistulas $(\mathrm{p}<0.05)$ (Table 1$)$.

In 21 cases $(4.87 \%)$ reinterventions were required - 12 for anastomotic fistulas, 5 for postoperative intestinal occlusion, 3 for Pezzer cecostomy removal and one for enteral fistula (in a patient who had an enterectomy practiced in an emergency) (Fig. 5).

Reinterventions were associated with resections with anastomosis per primam (p_value $=0.000014$ Likelihood Ratio), lymph node dissection $(\mathrm{p}<0.01)$ or patients with open I semi-open abdomen $(\mathrm{p}<0.04)$ (Table 1$)$. Reinterventions were not associated with an ileostomy, splenectomy, liver biopsy or other associated interventions (Table 1). The postoperative mortality was 9,28\% (Fig. 6).

Postoperative mortality was not associated with the type of main intervention, splenectomy, liver biopsy, and other associated interventions. The postoperative mortality was associated with lymph node dissection $(\mathrm{p}<0.01)$, ileostomy

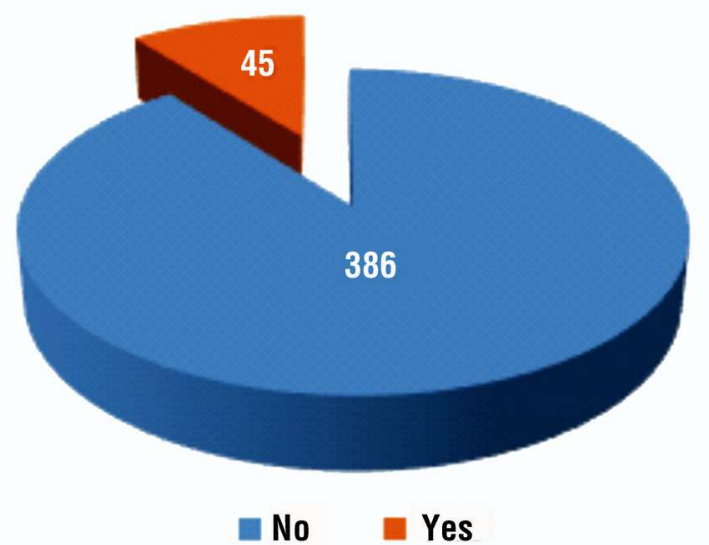

Figure 3. The distribution of cases according to postoperative morbidity

$(\mathrm{p}<0.01)$ and with the open / semi-open abdomen $(\mathrm{p}<0.04)$ (Table 1).

Most of the patients included in the study had a hospitalization period between 8 and 17 days, with an average number of 13.55 (Fig. 7 ). Correlating the types of surgery with the number of days of hospitalization, we found a statistically association between the

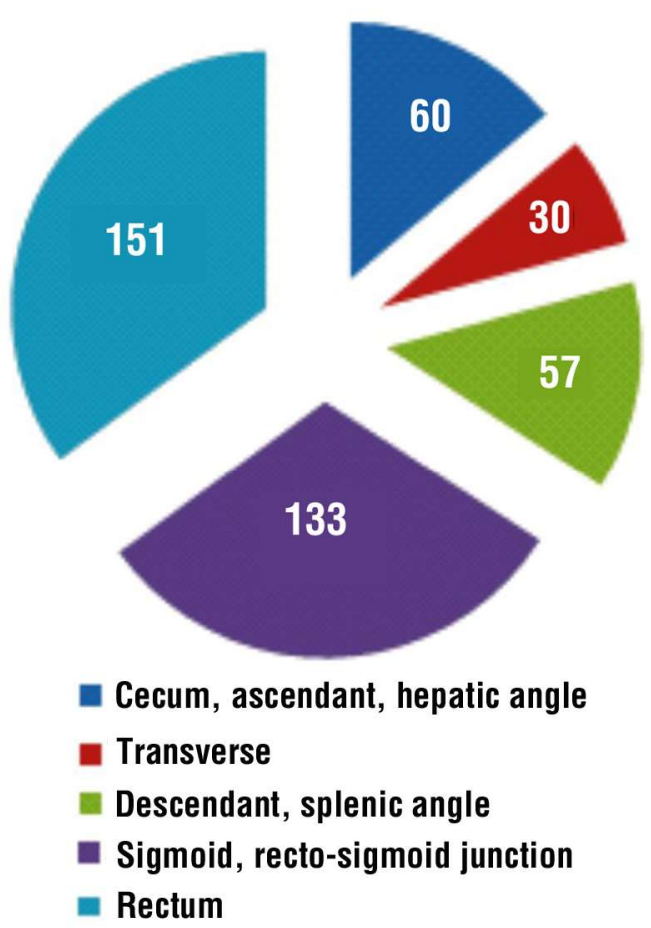

Figure 4. Frequency of postoperative complications 
Table 1. Statistical correlations of postoperative morbidity and mortality with surgery

\begin{tabular}{|c|c|c|c|c|c|c|c|}
\hline & $\begin{array}{l}\text { Postop. } \\
\text { complications } \\
=\text { yes }(\mathrm{N}=45)\end{array}$ & $\begin{array}{l}\text { Parietal } \\
\text { suppurations } \\
=\text { yes }(\mathrm{N}=23)\end{array}$ & $\begin{array}{l}\text { pseudomembr. } \\
\text { colitis }= \\
\text { yes }(\mathrm{N}=5)\end{array}$ & $\begin{array}{l}\text { fistulas = } \\
\text { yes } \\
(\mathrm{N}=12)\end{array}$ & $\begin{array}{l}\text { Postop. } \\
\text { obstruction } \\
=\text { yes }(\mathrm{N}=5)\end{array}$ & $\begin{array}{l}\text { Reintervention } \\
=\text { yes } \\
(\mathrm{N}=23)\end{array}$ & $\begin{array}{l}\text { Postop. } \\
\text { deaths =yes } \\
(\mathrm{N}=40)\end{array}$ \\
\hline Type op $1(\mathrm{~N}=179)$ & $6 / 179$ & $6 / 179$ & $0 / 179$ & $0 / 179$ & $0 / 179$ & $4 / 179$ & 24/179 \\
\hline Type op $2(\mathrm{~N}=134)$ & $13 / 134$ & $13 / 134$ & $0 / 134$ & $0 / 134$ & $0 / 134$ & $2 / 134$ & $10 / 134$ \\
\hline Type op $3(\mathrm{~N}=29)$ & $3 / 29$ & $0 / 29$ & $1 / 29$ & $2 / 28$ & $0 / 29$ & $2 / 29$ & $2 / 29$ \\
\hline Type op $4(\mathrm{~N}=89)$ & $23 / 89$ & $4 / 89$ & $4 / 89$ & $10 / 88$ & $5 / 89$ & $15 / 89$ & $4 / 89$ \\
\hline p_value & $0.003258(2)$ & $0.028934(\mathrm{H})$ & $0.004278(\mathrm{H})$ & $0.832208(\mathrm{H})$ & $0.001132\left({ }^{\prime} H\right)$ & $0.000014(\mathrm{H})$ & $0.079785(\mathrm{H})$ \\
\hline \multicolumn{8}{|l|}{ Lymph node dissection } \\
\hline Yes $(N=76)$ & $18 / 76$ & $4 / 76$ & $4 / 76$ & $6 / 68$ & $4 / 76$ & $10 / 76$ & $0 / 76$ \\
\hline No $(N=355)$ & $27 / 355$ & $19 / 355$ & $1 / 355$ & $6 / 50$ & $1 / 355$ & $13 / 355$ & $40 / 355$ \\
\hline p_value & $0.002479\left({ }^{2}\right)$ & $1.000000\left(^{*}\right)$ & $0.003914\left(^{*}\right)$ & $0.572663\left({ }^{2}\right)$ & $0.003914\left(^{*}\right)$ & $0.002676\left(^{*}\right)$ & $0.002124\left({ }^{2}\right)$ \\
\hline \multicolumn{8}{|l|}{ lleostomy } \\
\hline Yes $(N=6)$ & $2 / 6$ & $1 / 6$ & $1 / 6$ & $0 / 6$ & $0 / 6$ & $0 / 6$ & $4 / 6$ \\
\hline No $(N=112)$ & 24/112 & $3 / 112$ & $4 / 112$ & $12 / 112$ & $5 / 112$ & $17 / 112$ & $2 / 112$ \\
\hline p_value & $0.206745\left(^{*}\right)$ & $0.190650\left(^{*}\right)$ & $0.233247\left(^{*}\right)$ & $1.000000\left(^{*}\right)$ & $1.000000\left(^{*}\right)$ & $0.591354\left(^{*}\right)$ & $0.000029\left(^{*}\right)$ \\
\hline \multicolumn{8}{|l|}{ Splenectomy } \\
\hline Yes $(N=7)^{\prime}$ & $2 / 7$ & $1 / 7$ & $0 / 7$ & $1 / 2$ & $0 / 7$ & $1 / 7$ & $0 / 7$ \\
\hline No $(\mathrm{N}=424)$ & $43 / 424$ & $22 / 424$ & $5 / 424$ & $11 / 116$ & $5 / 424$ & $22 / 424$ & $40 / 424$ \\
\hline p_value & $0.130901\left(^{*}\right)$ & $0.320679\left(^{*}\right)$ & $1.000000\left(^{\star}\right)$ & $0.193829\left(^{*}\right)$ & $1.000000\left(^{*}\right)$ & $0.320679\left(^{\star}\right)$ & $1.000000\left(^{*}\right)$ \\
\hline \multicolumn{8}{|l|}{ Hep. biopsy } \\
\hline Yes $(N=17)$ & $1 / 17$ & $1 / 17$ & $0 / 17$ & $0 / 5$ & $0 / 17$ & $1 / 17$ & $3 / 17$ \\
\hline No $(N=414)$ & $44 / 414$ & $22 / 414$ & $5 / 414$ & $12 / 113$ & $5 / 414$ & $22 / 414$ & $37 / 414$ \\
\hline p_value & $1.000000\left(^{*}\right)$ & $0.613477\left(^{*}\right)$ & $1.000000\left(^{*}\right)$ & $1.000000\left(^{*}\right)$ & $1.000000\left(^{*}\right)$ & $0.613477\left(^{*}\right)$ & $0.202431\left(^{\star}\right)$ \\
\hline \multicolumn{8}{|l|}{ Associated intervention } \\
\hline Yes $(N=12)$ & $2 / 12$ & $1 / 12$ & $0 / 12$ & $1 / 5$ & $0 / 12$ & $2 / 12$ & $1 / 12$ \\
\hline No $(N=419)$ & $43 / 419$ & $22 / 419$ & $5 / 419$ & $11 / 113$ & $5 / 419$ & $21 / 419$ & $39 / 419$ \\
\hline p_value & $0.090409\left(^{\star}\right)$ & $0.486695\left(^{*}\right)$ & $1.000000\left(^{*}\right)$ & $0.420788\left(^{*}\right)$ & $1.000000\left(^{*}\right)$ & $0.129838\left(^{*}\right)$ & $1.000000\left(^{*}\right)$ \\
\hline \multicolumn{8}{|l|}{ Abdominal closure } \\
\hline Yes $(N=416)$ & $40 / 416$ & $21 / 416$ & $5 / 416$ & $9 / 109$ & $5 / 416$ & $20 / 416$ & $31 / 416$ \\
\hline No $(N=15)$ & $5 / 15$ & $2 / 15$ & $0 / 15$ & $3 / 9$ & $0 / 15$ & $3 / 15$ & $9 / 15$ \\
\hline p_value & $0.041026\left(^{*}\right)$ & $0.187570\left(^{*}\right)$ & $1.000000\left(^{*}\right)$ & $0.048047\left(^{*}\right)$ & $1.000000\left(^{*}\right)$ & $0.039698\left(^{*}\right)$ & $0.039698\left(^{*}\right)$ \\
\hline
\end{tabular}

Type op 1- colostomy, Type op 2 - Hartmann procedure, Type op 3 - internal derivations, Type op 4 - resections with anastomosis, $p$ value $\left({ }^{\star}\right)$ - Fisher's Exact Test,('H) - Likelihood Ratio, $\left({ }^{2}\right)$ - Pearson Chi-Square

number of days of hospitalization of patients with emergency colostomies compared to those of patients who had other types of interventions $(\mathrm{p}<0.01)$ (Table 2$)$.

For patients with Hartmann operations (N $=134)$, in $57(42.53 \%)$ of them, a stoma reversal

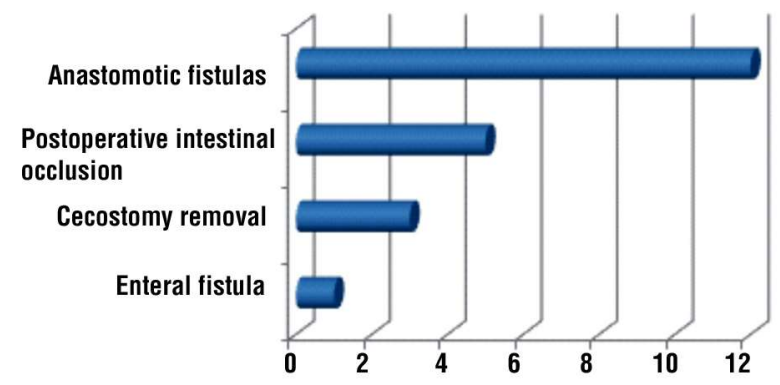

Figure 5. Distribution of the reinterventions practiced was practiced after an average interval of 5.7 months (Fig: 8). Of the patients with rectal tumors with colostomies in an emergency, 29 of them had Milles abdominal-perineal rectal amputations or Dixon rectal resections after an average interval of 5.8 months.

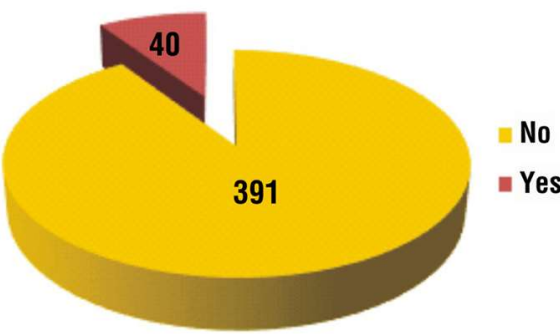

Figure 6. The distribution of cases according to postoperative mortality 


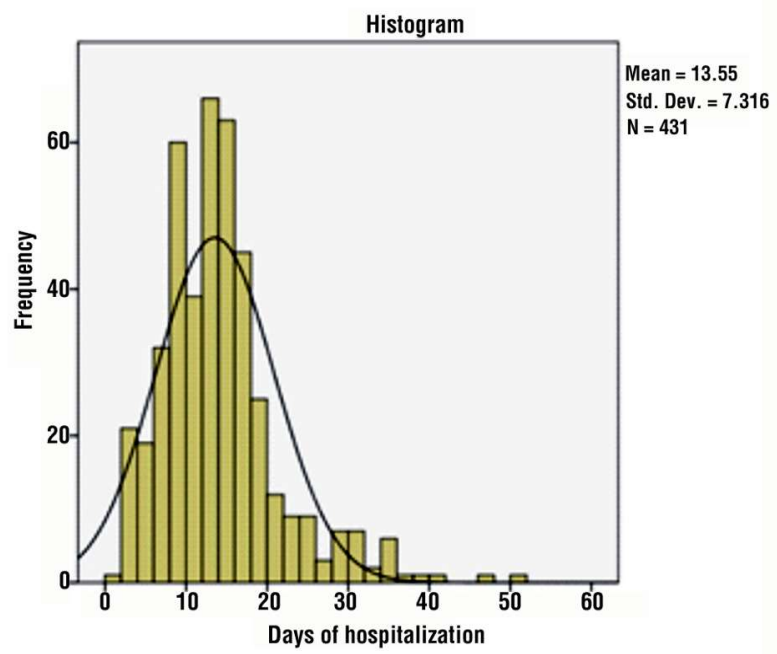

Figure 7. Length of hospitalization

\section{Discussions}

In this study, we showed that the negative prognostic factors for the postoperative morbidity and mortality of patients with colo-rectal cancer operated in an emergency were: the type of surgery (the resections with anastomosis had the highest rate of postoperative complications and reinterventions; the colostomies were associated with the highest postoperative mortality), practicing an ileostomy and lymph node dissection (higher postoperative mortality in these patients) and absence of abdominal closure (higher morbidity rates, reoperations and postoperative mortality in patients with open / semi-open abdomen).

Colorectal cancer is a major cause of morbidity and mortality and the emergency presentation increases the rate of complications and mortality even more. The choice of the type of operation depends on the location of the tumor, the biological and nutritional status of the patient, the age. For tumors on

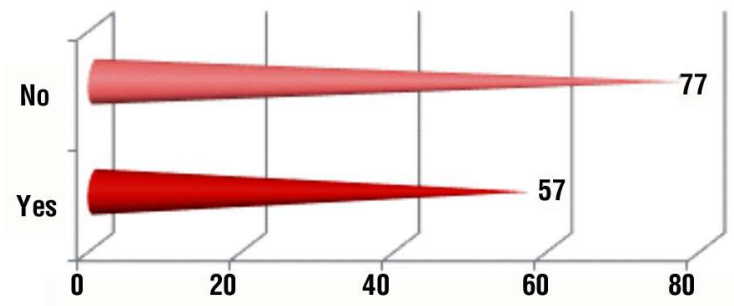

Figure 8. The distribution of patients with Hartmann procedure according to stoma reversal

the right colon, the most indicated is a right hemicolectomy, according to the majority of authors, but for those located on the left colon, the type of resection may be debatable (2).

Several studies and meta-analysis have shown that the higher postoperative mortality in elderly patients with complicated colorectal cancer is caused by pre-existing comorbidities and not by the emergency surgery itself (13-18).

A meta-analysis that included all the emergency colorectal cancer patients in France in 2006-2008 identified 6 factors that negatively influenced the postoperative mortality: age over 70, respiratory, vascular and neurological comorbidities, presence of liver metastases and malnutrition (19).

There has been an increasing tendency in recent years to practice resections with anastomosis for complicated colorectal cancer. A study conducted at the Royal Infirmary of Edinburgh, Scotland, from 1990 to 2000, which included 323 patients with colorectal cancer, operated in an emergency, reports much lower rates of postoperative morbidity and mortality for resections with anastomosis than for Hartmann operations (20), in contrast to the results of our study, in which we found the highest rates of morbidity and mortality in the cases of resections with anastomosis. Our findings are also supported by

Table 2. Correlation between the type of surgery and the length of hospitalization

\begin{tabular}{|c|c|c|c|c|c|}
\hline & $\begin{array}{l}\text { Type op }=1 \\
(N=179-41.5 \%)\end{array}$ & $\begin{array}{l}\text { Type op }=2 \\
(\mathrm{~N}=134-31.1 \%)\end{array}$ & $\begin{array}{l}\text { Type op=3 } \\
(\mathrm{N}=29-6.7 \%)\end{array}$ & $\begin{array}{l}\text { Type op=4 } \\
(\mathrm{N}=89-20.9 \%)\end{array}$ & $\begin{array}{l}\text { P_value } \\
\text { (test) }\end{array}$ \\
\hline $\begin{array}{l}\text { Number of } \\
\text { hospitalization days }\end{array}$ & $10.0(7.0,15.0)$ & $13.0(10.0,16.2)$ & $14.0(12.0,16.5)$ & $15.0(12.0,17.0)$ & $\begin{array}{l}0.000000 \\
\text { (Kruskal-Wallis Test) }\end{array}$ \\
\hline
\end{tabular}

Type op 1- colostomy, Type op 2 - Hartmann procedure, Type op 3 - internal derivations, Type op 4 - resections with anastomosis 
data from other research. Thus, in a retrospective study conducted between 2006-2013 at the University of Aberdeen, the UK, which included 67 patients with colorectal carcinomas, operated in an emergency, the authors report the Hartmann interventions as the most frequent and with the smallest rates of postoperative morbidity and mortality, similar to the data we obtained (21).

In 2004, Meyer et al. conducted a prospective multicenter non-randomized study comparing the results after emergency surgery for colorectal cancer of 213 patients with Hartmann procedures and 340 patients with resections with anastomosis. The mortality rate was higher in the cases of resections with anastomosis $(9.2 \%)$ compared to the Hartmann operations (7.5\%) (22).

In a study conducted in 2018 at Good Hope Hospital in Birmingham, which included 74 patients with complicated colorectal cancer who underwent Hartmann's surgery in 20082014 , this procedure is shown to be viable and its use justified, given the low risk of postoperative complications and almost zero mortality (23).

A recent study made at the University of Medicine and Pharmacy of Cluj-Napoca, which included 118 patients with colorectal cancer operated in an emergency, reports a postoperative mortality rate of $3.9 \%$. The authors obtained statistically significant differences between the practice or not of a protective ileostomy and postoperative mortality, similar to the data in our study (24).

The patients who present with complicated colon cancer are usually in an advanced stage of the disease and have a poor biological condition. In these cases, the utility of performing surgical resections that respect the oncological principles becomes questionable. In a study conducted at the University of Sao Paolo, Brazil, the authors reported a very high rate (71\%) of lymph node dissection in the group of patients, but at the same time, the postoperative morbidity was significant $(12 \%$ anastomotic fistulas) (25). We also found this correlation between lymph node dissection and postoperative complications in our study.
According to the latest recommendations from the international guidelines, the open abdomen has indications in severe peritonitis, with septic shock, when a second look for the source control is planned (degree of recommendation $2 \mathrm{C}$ according to WSES) (26). In a study conducted at the University Hospital of Istanbul, during 2000-2006, which included 37 patients with severe peritonitis, of which 14 by perforation of colorectal tumors, it is shown that these patients had the highest rates of postoperative morbidity and mortality (27), correlations that we also found. Studies on the use of laparostomy, including only emergency colorectal cancer patients, are missing from the literature.

\section{Conclusions}

1. The resections with anastomosis per primam and lymph node dissection were associated with statistically significant morbidity.

2 . The type of main surgery did not influence the postoperative mortality, this being associated with concomitant surgery: lymph node dissection, ileostomy and the way of closing the abdomen.

3 . The reinterventions were associated with resections with anastomosis per primam for anastomotic fistulas, with the practice of lymph node dissection and with the open/semi-open abdomen.

4. The duration of the hospitalization was significantly influenced by the type of main surgery, the smallest number of days of hospitalization being registered in the patients with colostomies.

\section{Conflicts of Interests}

The authors declare no conflicts of interest.

\section{Ethics Approval}

The study design was approved by the Ethic Committee of "Dunarea de Jos" University, Galati, Romania (nr. 1/22.02.2018), for a retrospective study in patients with colorectal 
cancer operated in emergency during 20082017 at the "Sf Ap Andrei" County Emergency Clinical Hospital Galati.

\section{References}

1. Smothers L, Hynan L, Fleming, J, Turnage R, Simmanq C, Anthony T. Emergency Surgery for Colon Carcinoma.Dis Colon Rectum 2003:46:24-30

2. Cuffy M, Abir F, Audisio R, Longo W. Colorectal cancer presenting as surgical emergencies. Surgical Oncology. 2004;13(2-3):149-157.

3. Patel SV, Patel SV, Brackstone M. Emergency surgery for colorectal cancer does not result in nodal understaging compared with elective surgery. Can J Surg. 2014;57(5):349-353.

4. Banaszkiewicz Z, Woda Ł, Tojek K, Jarmocik P, Jawień A. Colorectal cancer with intestinal perforation- a retrospective analysis of treatment outcomes. Contemp Oncol (Pozn). 2014;18(6):414-418.

5. Ansaloni L, Andersson RE, Bazzoli F, Catena F, Cennamo V, Di Saverio $S$ et al. Guidelines in the management of obstructing cancer of the left colon: consensus conference of the world society of emergency surgery (WSES) and peritoneum and surgery (PnS) society. World J EmergSurg. 2010;5:29.

6. Amri R, Liliana Bordeianou, Patricia Sylla, Berger D. Colon cancer surgery following emergency presentation: effects on admission and stage adjusted outcomes. American Journal of Surgery. 2015; 209(2):246-53

7. Poon RT, Law WL, Chu KW, Wong J. Emergency resection and primary anastomosis for left-sided obstructing colorectal carcinoma in the elderly. BJS. 1998;85(11):1539-1542 .

8. Pisano M, Zorcolo L, Merli C, Cimbanassi S, Poiasina E, Ceresoli M et al. 2017 WSES guidelines on colon and rectal cancer emergencies: obstruction and perforation. World J Emerg Surg. 2018;13:36.

9. Medina Villasenor E, Quezada Adame I, Martinez Macias R, Elvia Neyra Ortiz, Parra PAO, Cruz MR. Urgencias gastrointestinales en el paciente con cancer. Acta Medica Grupo Angeles 2011:9(3):136-142.

10. Ramos RF, Santos Dos-Reis LC, Beatriz Esteves Borgeth Teixeira, Andrade IM, Jaqueline Suelen Sulzbach, Leal RA. Cirurgia no cancer de colon em pacientes operados de emergencia. Rev Col Bras Cir. 2017;44(5):465-470.

11. Tebala GD, Natili A, Gallucci A, Brachini G, Khan AQ, Tebala D et al. Emergency treatment of complicated colorectal cancer. Cancer Manag Res. 2018;10:827-838.

12. Shankar A, Taylor I. Colorectal cancer. In: Holzheimer RG, Mannick JA, editors. Surgical Treatment: Evidence-Based and ProblemOriented. Munich: Zuckschwerdt; 2001. Available from:
https://www.ncbi.nIm.nih.gov/books/NBK6898/

13. Marusch F, Koch A, Schmidt U, et al. Impact of age on the shortterm postoperative outcome of patients undergoing surgery for colorectal carcinoma.Int J Colorectal Dis. 2002;17:177-184,

14. Arnaud JP, Schloegel M, Ollier JC, Adloff M. Colorectal cancer in patients over 80 years of age. Dis Colon Rectum. 1991;34: 896-898,

15. Frizis H, Papadopoulos A, Akritidis G, et al. Are there any differences in colorectal cancer between young and elderly patients? Tech Coloproctol.2004;8(Suppl 1):s147-s148,

16. Hellinger $A$. Is oncological surgery contraindicated in the older patient? MMW Fortschr Med. 2004;146:22-24.

17. Zhang B, Fattah A, Nakama $\mathrm{H}$. Characteristics and survival rate of elderly patients with colorectal cancer detected by immunochemical occult blood screening. Hepatogastroenterology. 2000; 47:414-418.

18. Pedrazzani C, Cerullo G, De Marco G, Marrelli D, Neri A, De Stefano A. et al. Impact of age-related comorbidity on results of colorectal cancer surgery. World J Gastroenterol. 2009;15(45):5706-5711.

19. Panis I, Maggiori L, Caranhac G, Bretagnol F, Vicaut E. Mortaliy after colorectal cancer surgery- a French survey of more than 84000 patients. Ann Surg 2011; 254(5):738-743.

20. Zorcolo L, Covotta L, Carlomagno N, Bartolo DC. Safety of primary anastomosis in emergency colo-rectal surgery. Colorectal Dis.2003;5(3):262-269.

21. Ng HJ, Yule M, Twoon M, Binnie NR, Aly EH.Current outcomes of emergency large bowel surgery.Ann $\mathrm{R}$ CollSurg Engl. 2015:97(2):151-156.

22. Meyer F, Marusch F, Koch A, Meyer L, Fuhrer S, Kockerling F. et al. Emergency operations in carcinomas of the left colon: value of Hartmann's procedure. Tech Coloproctol 2004; 8Supl 1:s226-9

23. Hallam S, Mothe BS, Tirumulaju R. Hartmann's procedure, reversal and rate of stoma-free survival. Ann R CollSurg Engl. 2018; 100(4):301-307.

24. Miana Gabriela Pop, Dana Monica Bartoș, Ana Maria Fiț et al. Thirtyday postoperative mortality in colon cancer surgery. A single center analysis of 630 patients. HVM Bioflux 2018; 10(2): 69-73

25. Teixeira F, Akaishi EH, Ushinohama AZ, Dutra TC, Do Couto Netto $\mathrm{SD}$, Utiyama EM. et al. Can we respect the principles of oncologic resection in an emergency surgery to treat colon cancer?.World J Emerg Surg. 2015;10:5

26. Coccolini F, Montori G, Ceresoli M, Catena F, Moore EE, Ivatury R. et al. The role of open abdomen in non-trauma patient: WSES Consensus Paper. World J Emerg Surg. 2017;12:39

27. Gonollu D, Koksoy FN, Demiray 0, Ozkan SG, Yucel T, Yucel 0. Laparostomy in patients with severe secondary peritonitis. Turkish Journal of Trauma\&Emergency Surgery. 2009;15(1):52-57. 